\title{
MANIPULASI TOPURAK (TOTOK, PUKUL, GERAK) UNTUK PENYEMBUHAN NYERI DAN KETEGANGAN OTOT LEHER
}

\author{
Ela Yuliana ${ }^{1}$, B.M Wara Kushartanti ${ }^{1}$ \\ ${ }^{1}$ Fakultas Ilmu Keolahragaan, Universitas Negeri Yogyakarta, Jl. Colombo No. 1, Karangmalang, Depok, Sleman, \\ Daerah Istimewa Yogyakarta, Indonesia \\ elayuniana.2018@student.uny.ac.id,bm_warakushartanti@uny.ac.id
}

\begin{abstract}
Abstrak
Nyeri dan ketegangan otot leher merupakan keluhan muskuloskeletal umum yang sering dirasakan setiap orang (prevalensi 30\%-50\%). Topurak (Totok, Pukul, Gerak) merupakan salah satu terapi manipulasi. Tujuan penelitian ini adalah untuk menguji efektivitas manipulasi Topurak untuk penyembuhan nyeri dan ketegangan otot leher pasien Klinik Olahraga Terapi dan Rehabilitasi FIK UNY. Rancangan Pre-experimental dengan One Group Pretest-Posttest Design. Teknik pengambilan sampel menggunakan quota sampling yang dihitung dengan rumus Slovin didapatkan quota sebesar 15 orang. Data yang dikumpulkan adalah ROM, skala nyeri, dan skala fungsi baik sebelum maupun sesudah perlakukan. Paired Samples $t$ Test digunakan untuk menganalisis data ROM dan uji Wilcoxon untuk data skala nyeri maupun skala fungsi. Hasil penelitian menunjukkan adanya peningkatan ROM pada gerakan fleksi, ekstensi, left lateral flexion, right lateral flexion, left rotation, dan right rotation. Didapatkan juga adanya penurunan skala nyeri serta peningkatan skala fungsi leher setelah manipulasi Topurak $(p<0,05)$. Berdasarkan hasil tersebut, maka dapat disimpulkan bahwa manipulasi Topurak efektif untuk penyembuhan nyeri dan ketegangan otot leher.
\end{abstract}

Kata kunci: terapi manipulasi, nyeri dan ketegangan otot leher

\section{TOPURAK MANIPULATION (TOUCH, PUNCH, MOTION) FOR HEALING OF PAIN AND NECK MUSCLE TENSION}

\begin{abstract}
Neck pain and muscle tension is a common musculoskeletal complaint that is often felt by everyone (prevalence of 30\% -50\%). Topurak (Touch, Pukul, Motion) is a manipulation therapy. and neck muscle tension of FIK UNY Sports and Therapy Sports and Rehabilitation Clinic patients. Pre-experimental design with One Group Pretest-Posttest Design. The sampling technique uses quota sampling which is calculated by Slovin formula obtained quota of 15 people. Data collected were ROM, pain scale, and function scale both before and after treatment. Paired Samples $t$ Test is used to analyze ROM data and Wilcoxon test for pain scale and function scale data. The results showed an increase in ROM in flexion, extension, left lateral flexion, right lateral flexion, left rotation, and right rotation. There was also a decrease in pain scale and an increase in the scale of neck function after Topurak manipulation ( $p$ $<0.05)$. Based on these results, it can be concluded that Topurak manipulation is effective for healing neck pain and muscle tension.
\end{abstract}

Keywords: manipulation therapy, pain and neck muscle tension

\section{PENDAHULUAN}

Di era modern seperti ini, banyak orang menghabiskan waktu seharian untuk menyelesaikan pekerjaan maupun tugas-tugasnya tanpa memperdulikan efek samping yang ditimbulkan. Beberapa efek samping yang ditimbulkan dapat berupa kelelahan fisik seperti 
keluhan pada otot, sendi, dan tulang yang dapat menyebabkan kondisi tubuh menurun serta mengalami gangguan dalam beraktivitas.

Leher sebagai bagian dari anggota tubuh bagian atas merupakan bagian tubuh yang berfungsi sebagai penopang kepala dan merupakan bagian dari batang tubuh atau tulang belakang, sehingga leher memiliki struktur yang yang kompleks dan sangat rentan terhadap iritasi maupun gangguan muskuloskeletal. Menurut Hogg-Johnson et al. (2008: 47) prevalensi nyeri leher dalam satu bulan berkisar antara $15,4 \%$ sampai $45,3 \%$ pada orang dewasa dan 4,5\% sampai $8,5 \%$ pada anak-anak/remaja, selain itu prevalensi satu bulan nyeri leher yang mengganggu aktivitas pada orang dewasa berkisar antara 7,5\% sampai $14,5 \%$

Manipulasi Topurak merupakan salah satu terapi yang terdiri atas totok, pukul, dan gerak yang sebelumnya telah diteliti untuk reposisi subluksasi bahu dan penyembuhan cedera sendi lutut. Manipulasi Topurak untuk reposisi subluksasi bahu diteliti oleh Rachmah Laksmi Ambardini dan B.M. Wara Kusharanti pada tahun 2016 yang diketahui memiliki efektivitas untuk reposisi sendi bahu dengan ditandai meningkatnya ROM, mengurangi nyeri akibat subluksai bahu, dan efektif dalam mereposisi bahu. Manipulasi Topurak untuk penyembuhan cedera sendi lutut diteliti oleh Muhammad Fathur Rohim pada tahun 2017 diketahui memiliki efektivitas untuk penyembuhan cedera sendi lutut yang ditandai dengan berkurangnya radang (merah, panas, bengkak, dan nyeri), serta meningkatnya fungsi sendi lutut untuk kegiatan sehari-hari (jalan, berdiri dari duduk, dan naik tangga) dengan signifikan.

Manipulasi Topurak dilakukan dengan menekan (totok) pada trigger point untuk proses pelemasan otot sehingga dapat mengurangi kekakuan atau ketegangan otot. Pukul atau tapotement untuk menyempurnakan pelemasan otot, sehingga lingkup gerak sendi meningkat dan nyeri akan berkurang. Gerak yang dilakukan pasien dengan instruksi dari terapi dapat mengembalikan sendi ke posisi yang benar, dan meregangkan otot yang kaku/tegang sehingga menjadi lebih rileks. Keunggulan dari manipulasi Topurak adalah dapat merelaksasikan otot, mengurangi nyeri, dan melibatkan pasien secara aktif sehingga lebih aman karena pasien melakukan sesuai dengan kekakuan dan nyeri yang dirasakan (Ambardini et al., 2016: 74).

Leher merupakan bagian dari tulang belakang yang tersusun atas serangkaian tulang yang terpisah, dan dipisahkan oleh bantalan fibrokartilago atau disebut discus intervertebralis. Di dalam leher terdapat bagian penting seperti pembuluh, saraf, dan kelenjar endokrin, (Moore et al., 2002: 409). Leher didukung dan diperkuat oleh komponen penyusun tulang leher sehingga dapat berdiri tegak dan menjadi satu kesatuan unit fungsional yang utuh. Komponen tersebut antara lain:

\section{Tulang}

Tulang merupakan alat gerak pasif yang memberi bentuk tubuh, pelindung organ vital, dan tempat melekatnya otot sehingga memungkinkan terjadinya gerakan (Luklukaningsih, 2011: 2). Samara (2007: 139) mengatakan, leher tersusun atas 7 tulang vertebra yang dimulai dari dasar kranium dan berakhir di atas vertebra torakal (C1-C7). Tulang vertebra penyusun leher antara satu dengan yang lain memiliki perbedaan dan ciri yang khas. Menurut Anderson et al. (2009: 270) ciri-ciri tulang vertebra pada daerah leher antara lain: 1) Atlas atau tulang vertebra pertama pada leher (C1) tidak memiliki tubuh atau spinous processes. Sebaliknya, atlas memiliki lengkungan anterior dan posterior yang tebal, massa lateral. Atlas menghubungkan tulang tengkorak dengan tulang belakang dan berfungsi untuk menganggukkan kepala (France, 2011: 587)., 2) Axis merupakan tulang vertebra kedua pada leher yang memiliki karakteristik seperti gigi yang disebut odontoid processus yang menonjol ke atas dari badan axis. Axis membentuk poros di mana atlas berputar, dan memungkinkan kita untuk menolehkan kepala kita (France, 2011: 587)., 3) Transverse processes pada ruas tulang leher yang memiliki foramen atau disebut transverse foramen yang terletak pada setiap sisi badan vertebra untuk dilalui arteri vertebralis, pembuluh darah, dan saraf., 4) Spinous processes 
pada ruas tulang leher C2-C6 memiliki ujung yang terpecah dua belah atau bifida., 5) Ruas tulang leher ketujuh (C-7) memiliki spinous processes yang besar dengan ujung yang agak bulat.

\section{Otot}

Otot merupakan jaringan dalam tubuh yang memiliki struktur yang teratur. Jaringan otot (kontraktil) terdiri atas sel yang disebut serabut otot. Setiap serabut otot mengandung ratusan hingga ribuan miofibril. Setiap miofibril tersusun sekitar 1500 filamen miosin yang saling berdekatan dan 3000 filamen aktin, yang merupakan filamen protein yang interaksinya menyebabkan pergerakan (Guyton et al., 2006: 74). Menurut Setiadi Budiyono (2013: 5) yang dikutip oleh Budiono (2016: 14), tugas utama dari otot adalah mengkontraksikan otot dan menggerakan bagian tubuh baik yang disadari atau tidak. Cailliet (1981: 21-22) membagi otot leher menjadi dua kelompok utama, yaitu: Otot yang berfungsi menggerakan kepala ke arah fleksi dan ekstensi (capital movers). Capital movers terdiri atas capital extensors dan capital flexors. Capital extensors melekat pada tengkorak dan menggerakan kepala di atas leher. Otot yang berfungsi sebagai capital extensors, antara lain: rectus capitis minor, rectos capitis major, obliquus capitis superior, dan obliquus capitis inferior. Capital flexors berfungsi untuk menggerakkan kepala ke arah fleksi di atas leher. Otot yang berfungsi sebagai capital flexors, antara lain: longus capitis, rectus capitis anterior, rectus capitis lateral, hyoideus, dan suprahyoid.

Topurak merupakan manipulasi otot, pukul dan gerak yang dapat merelaksasikan jaringan yang mengalami spasme, mengurangi nyeri, dan mengembalikan sendi ke posisi anatomis. Menurut Ambardini et al. (2016: 73) manipulasi Topurak (totok, pukul dan gerak) dimulai dengan penekanan pada trigger point (totok) yang akan mempercepat pelemasan otot, tapotement (pukul) akan menyempurnakan pelemasan sehingga mengurangi nyeri saat digerakkan, dan Gerak yang dilakukan oleh pasien sendiri sesuai dengan kekakuan dan nyeri yang dirasakan dengan instruksi dari terapi akan mengembalikan sendi keposisi yang benar serta merelaksasikan otot yang mengalami kekakuan.

Manipulasi Topurak Menurut Ambardini et al. (2016: 82) manipulasi Topurak dibagi menjadi tiga tahap, yaitu: 1) Trigger point adalah daerah kecil atau suatu titik yang sangat sensitif terletak di struktur otot yang menegang dan dapat menyebabkan nyeri, kekakuan otot, terbatasnya Range of Motion (ROM) dan disfungsi motorik (Wilke et al., 2014: 836). Menurut Tough et al., (2009: 3-10) yang dikutip oleh Atmadja (2016: 176) daerah kecil ini apabila diberikan tekanan dapat menyebabkan nyeri lokal atau menjalar. Terdapat hipotesis bahwa trigger point dapat memperpendek serat otot sehingga menghasilkan matriks inelastis yang lemah yang mengurangi elastisitas jaringan lunak sekitarnya. Hal ini menyebabkan perubahan hubungan panjang-ketegangan dalam otot, yang dapat merubahan hambatan timbal-balik, perubahan hubungan force-couple, gerakan sendi yang tidak normal (Abels, 2013: 5). Trigger point pada manipulasi Topurak yaitu totok atau menekan menggunakan jari tangan dengan tekanan yang cukup di area trigger point bahu dan leher yang berfungsi untuk mempercepat proses relaksasi. Menekan keras pada trigger point juga dapat mengurangi rasa sakit, meningkatkan gerakan, dan memungkinkan otot memanjang (relaksasi) serta mengembalikan kekuatan otot (Motimath et al., 2017: 208). Menurut Kalichman et al. (2016: 448) penekanan pada trigger point diyakini dapat mengaktifkan sistem saraf otonom dengan merangsang reseptor interstisial tipe III dan IV yang merespons sentuhan ringan; tekanan berkelanjutan dapat merespons ruffini di fasia sehingga menurunkan nada simpatik keseluruhan, meningkatkan aktivitas neuron motor gamma dan mendorong relaksasi sel otot polos intrafascial. Selain itu, diyakini bahwa sistem saraf otonom mendorong vasodilatasi dan dinamika fluida lokal yang mengubah viskositas fasia dengan mengubah substansi keras menjadi keadaan yang lebih mirip gel. Semua proses tersebut menghasilkan pelepasan trigger point yang jelas 
dan memperbaiki fungsi otot., 2) Tahap kedua dari manipulasi Topurak yaitu tapotement (memukul). Tapotement merupakan gerakan menggunakan dua tangan yang kuat dan cepat seperti hacking, beating, dan clapping untuk meningkatkan aliran darah dan merangsang ujung saraf perifer (Anderson et al., 2009: 186). Selain itu, Tapotement dilakukan untuk menyempurnakan proses pelemasan otot dan mengurangi rasa nyeri akibat tekanan yang dilakukan pada trigger point. Sesuai dengan Gate Control Theory oleh Melzack et al. (1965) yang dikutip Moyer et al. (2004: 5) rasa nyeri dapat dikurangi dengan rangsangan seperti tekanan atau dingin, karena rangsangan ini berjalan di sepanjang jalur sistem saraf yang lebih cepat daripada rasa nyeri, sehingga tekanan yang cukup akan menciptakan stimulus yang mengganggu transmisi rangsangan rasa nyeri ke otak, secara efektif "menutup pintu gerbang" terhadap pesan nyeri, sebelum nyeri diproses oleh otak., 3) Gerak . Tahap ini dilakukan dengan cara meminta pasien untuk menggerakan leher dan bahu sesuai gerakan yang terinstruksi dengan keluasan sesuai nyeri dan kekakuan yang dirasakan pasien. Gerakan dilakukan dengan tujuan, jika terdapat sendi pada posisi yang tidak benar, maka dapat mengembalikan sendi ke posisi semula. Selain itu menurut Cailliet, (1991) yang dikutip oleh Wibawa et al. (2015: 8) gerakan dilakukan untuk mengkontraksikan otot sementara kemudian direlaksasikan. Efek relaksasi setelah kontraksi otot dapat meningkatkan sirkulasi ke area nyeri, sehingga zat-zat yang menimbulkan nyeri dapat dikeluarkan dari jaringan.

Leher merupakan bagian tubuh yang rentan, tidak heran jika nyeri leher merupakan keluhan yang umum dirasakan oleh setiap orang. Penggunaan yang berulang-ulang, posisi statis yang lama, dan trauma merupakan faktor penyebab timbulnya nyeri dan ketegangan otot leher. Nyeri dan ketegangan leher merupakan keluhan pada muskuloskeletal yang menyebabkan nyeri, ketegangan otot, lingkup gerak sendi menjadi terbatas, sehingga menurunkan fungsi leher. Topurak (totok, pukul, gerak) merupakan manipulasi yang dilakukan dengan cara menekan atau totok pada trigger point untuk merelaksasikan otot yang mengalami kekakuan. Pukul atau tapotement untuk menyempurnakan pelemasan otot, dan mengurangi nyeri akibat totok pada trigger point. Gerak yaitu dengan melibatkan pasien secara langsung dengan menggerakkan bahu dan dilanjutkan leher dengan gerakan terintruksi dari terapis untuk mengembalikan sendi pada posisi anatomi, dan meregangkan otot yang kaku/tegang.

\section{METODE}

Desain penelitian yang digunakan dalam penelitian ini adalah Pre-experimental dengan rancangan One Group Pretest-Posttest Design, yaitu terdiri atas satu kelompok, tanpa adanya kelompok kontrol. Proses penelitian dilaksanakan dalam tiga tahap yaitu, pretest, perlakuan, dan posttest. Hasil dari perlakuan yaitu perbedaan antara nilai pretest dan posttest (Yusuf, 2014: 181). Penelitian dilakukan pada bulan Oktober-Desember 2017 di Klinik Olahraga Terapi dan Rehabilitasi FIK UNY. Populasi dalam penelitian ini adalah pasien Klinik Olahraga Terapi dan Rehabilitasi FIK UNY. Penelitian ini diperkirakan berjalan selama tiga bulan maka penentuan jumlah populasi dilakukan dengan menghitung jumlah pasien tiga bulan terakhir, dan ternyata didapatkan adanya 28 pasien.

Pemeriksaan dilakukan dengan melihat (look), meraba/palpasi (feel), dan menggerakan (move). Pemeriksaan dengan cara melihat (look) bertujuan untuk pemeriksaan tanda radang yaitu merah dan bengkak. Palpasi/diraba (feel) tepat pada leher bertujuan untuk merasakan adanya bengkak dan panas, kemudian dibandingkan dengan sisi yang normal. Semakin panas dan semakin terlihat bengkak saat diraba, semakin banyak nilai (+). Selain itu, palpasi (feel) juga dilakukan untuk pemeriksaan terutama pada skala nyeri tekan. Skala nyeri diukur menggunakan Numerica Rating Scale (NRS) dengan intensitas rasa nyeri yang diraskan dari angka 0-10. Semakin nyeri yang dirasakan semakin tinggi angka skala nyeri dan sebaliknya. Gerak (move) digunakan untuk pemeriksaan ROM pada leher sekaligus menggukur besar sudut dengan satuan derajat menggunakan Goniometer. Gerak (move) juga digunakan untuk 
pemeriksaan skala fungsi yang dinilai dengan angka 0-10. Semakin terganggu fungsi gerak akibat cedera, semakin rendah angka skala fungsi dan sebaliknya.

\section{Teknik Analisis Data}

Data penelitian yang telah diperoleh, selanjutnya akan dianalisis dengan beberapa cara, antara lain: 1) Data berskala nominal dan ordinal dianalisis menggunakan deskriptif kuantitatif; 2) Data bagi data yang berskala interval dan rasio dianalisis menggunakan uji beda dua kelompok berpasangan baik yang parametrik maupun non-parametrik tergantung normalitas sebaran data.

\section{HASIL DAN PEMBAHASAN}

Lokasi yang digunakan dalam melaksanakan penelitian ini adalah Klinik Olahraga Terapi dan Rehabilitasi FIK UNY yang dalam hal ini dilakukan di Poliklinik UNY. Subjek dalam penelitian ini merupakan pasien Klinik Olahraga Terapi dan Rehabilitasi FIK UNY selama bulan Oktober-Desember 2017 yang mengalami nyeri dan ketegangan otot leher sampai menggangu fungsi gerak leher.

Subjek dalam penelitian ini berjumlah 15 orang dengan rincian 10 orang laki-laki, dan 5 orang perempuan, sehingga didapatkan persentase pasien laki-laki sebesar 66,7\%, dan pasien perempuan sebesar 33,3\%. Rentang usia dari subjek penelitian ini berkisar pada 19-24 tahun, dengan rata-rata berusia 21,7 tahun dan standar deviasi 2,5. Rata-rata pekerjaan yang dimiliki subjek penelitian yaitu sebagai mahasiswa berumlah 13 dengan persentase $86,7 \%$. Sembilan dari 13 mahasiswa sebagai subjek penelitian memiliki profesi sebagai olahragawan yaitu berjumlah 9 orang. Berat badan dari subjek penelitian ini berkisar antara 45-75,5 kg, dengan rata-rata berbobot $62,57 \mathrm{~kg}$ dan standar deviasi 8,94. Tinggi badan dari subjek penelitian adalah $151-180 \mathrm{~cm}$ dengan rata-rata $165,23 \mathrm{~cm}$ dan standar deviasi 8,70 . Pengukuran yang dilakukan terhadap 15 subjek dalam penelitian ini meliputi ROM, skala nyeri, dan skala fungsi.

\section{Deskripsi Data Penelitian}

Data yang didapatkan dalam penelitian ini berdasarkan anamnesa, dan pemeriksaan sebelum dan setelah perlakuan. Data tersebut dianalisis secarabdeskriptif dengan tujuan untuk mempermudah penyajian data penelitian. Hasil analisis deskriptif pada masing-masing data penelitian adalah sebagai berikut: 1) Durasi Cedera. Penelitian ini melakukan pengelompokan durasi cedera ke dalam tiga kelompok, yaitu fase akut, fase subakut, dan fase kronis. Fase akut berlangsung selama kurang dari 7 hari, fase sub akut berlangsung selama 7 hari sampai 6 minggu, dan fase kronis berlangsung selama lebih dari 6 minggu., 2) Penyebab Cedera. Penyebab cedera dalam penelitian ini dikelompokan menjadi tiga, yaitu posisi statis yang lama, gerakan berulang, dan trauma, diketahui bahwa 6 subjek dengan persentase $40 \%$ disebabkan oleh posisi statis yang lama, yaitu bekerja di depan layar (laptop/komputer) dengan waktu yang lama, berkendara motor/mobil dengan jarak yang jauh tanpa istirahat, dan posisi yang salah ketika istirahat (tidur) seperti menggunakan bantal yang terlalu tinggi, atau menggunakan bantal yang terlalu tendah. Sejumlah 3 subjek dengan persentase $20 \%$ yang disebabkan oleh gerakan berulang, yaitu saat berolahraga seperti gym dan kurangnya stretching atau cooling down sebelum atau setelah olahraga. Sebanyak 6 subjek dengan persentase $40 \%$ yang disebabkan oleh trauma. Trauma yang dialami oleh subjek penelitian adalah benturan (body contact) dengan pemain lawan maupun tim saat bertanding olahraga, posisi yang salah saat berolahraga sehingga terjatuh, dan terjatuh ketika berkendara., 3) Riwayat Cedera. Penelitian ini mengelompokkan riwayat cedera menjadi empat, yaitu cedera bahu, cedera leher, cedera regio lain, dan tidak pernah cedera. riwayat cedera terbanyak adalah cedera bahu dengan jumlah 7 subjek dan persentase 46,7 \%., 4) Sisi Cedera. Sisi cedera dalam penelitian ini dibagi menjadi 3 , yaitu kanan, kiri, dan tengah. sisi kanan merupakan sisi cedera yang terbanyak dibandingkan dengan sisi kiri dan tengah. Sisi cedera bagian kanan berjumlah 7 dengan persentase 46,7\%., 
5) Range of Motion (ROM). Hasil pengukuran ROM menggunakan Goniometer terhadap 15 subjek penelitian sebelum dan setelah dilakukan manipulasi Topurak rata-rata data ROM seperti fleksi, ekstensi, left lateral flexion, right lateral flexion, left rotation, dan right rotation terjadi peningkatan setelah dilakukan manipulasi Topurak. Menurut Ambardini et al. (2016: 78) manipulasi Topurak memberikan efek fisiologi yaitu menimbulkan relaksasi pada otot, sehingga dapat meningkatkan ROM. Persentase efektivitas peningkatan ROM setelah dilakukan manipulasi Topurak dihitung berdasarkan nilai rata-rata dari pretest dan posttest., 6) Skala Nyeri. Skala nyeri diukur dengan Numerical Rating Scale (NRS) dengan angka 0-10. Semakin terasa nyeri yang dirasakan semakin tinggi skala. Hasil pemeriksaan skala nyeri terhadap 15 subjek penelitian sebelum dan setelah dilakukan manipulasi Topurak terjadi penurunan skala nyeri yang dirasakan oleh subjek penelitian setelah dilakukan manipulasi Topurak. karena totok, pukul, dan gerak memiliki efek terhadap penurunan nyeri. Persentase efektivitas penurunan skala nyeri setelah dilakukan manipulasi Topurak, dihitung berdasarkan nilai rata-rata dari pretest dan posttest., 7) Skala Fungsi. Skala Fungsi diukur dengan skala 010. Semakin baik skala fungsi, semakin tinggi skala. Hasil pemeriksaan skala fungsi sebelum dan setelah dilakukan manipulasi Topurak skala fungsi mengalami peningkatan setelah dilakukan manipulasi Topurak. Peningkatan skala fungsi terjadi karena otot yang sebelumnya mengalami ketegangan setelah dilakukan manipulasi Topurak menjadi lebih relaks sehingga nyeri yang diraskan akibat ketegangan otot menjadi lebih berkurang. Selain itu, dengan relaksasi otot juga berpengaruh ROM menjadi lebih luas. Akibatnya skala fungsi menjadi lebih baik atau meningkat setelah dilakukan Manipulasi Topurak. Persentase efektivitas peningkatan skala fungsi setelah dilakukan manipulasi Topurak dihitung berdasarkan nilai rata-rata dari pretest dan posttest.

\section{SIMPULAN}

Berdasarkan hasil penelitian yang telah diperoleh, maka dapat disimpulkan bahwa manipulasi Topurak efektif untuk penyembuhan nyeri dan ketegangan otot leher yang ditunjukkan dengan terjadinya peningkatan ROM, penurunan skala nyeri, dan peningkatan skala fungsi setelah dilakukan manipulasi Topurak.

\section{DAFTAR PUSTAKA}

Abels, K.M. (2013). The Impact of Foam Rolling on Explosive Strength and Excitability of the Motor Neuron Pool. Tesis. Austin: The University of Texas at Austin.

Admadja, A.S. (2016). Sindrom Nyeri Myofascial. Continuing Medical Education, 43 (3), 176179.

Ambardini, R.L. \& Kushartanti, B.M.W. (2016). Efektivitas Masase Topurak untuk Reposisi Subluksasi Bahu. Proceedings FIK UNY. Hlm 73-82.

Arovah, N.I. (2010). Diagnosa dan Manajemen Cedera Olahraga. Yogyakarta: FIK UNY.

Ashwini, T.M., Karvannan, H., \& Prem, V. (2017). Effects of Movement Impairment Based Treatment in The Management of Mechanical Neck Pain. Journal of Bodywork and Movement Therapies, 30, 1-6.

Cailliet, R. (1981).Neck and Arm Pain. California: F.A Davis Company.

Hogg-Johnson, S., Van der Velde, G., Carroll, L.J., Holm, L.W., et al. (2008). The Burden and Determinants of Neck Pain in The General Population. Results of The Bone and Joint Decade 2000-2010 Task Force on Neck Pain and Its Associated Disorders. Journal of Manipulative and Physiological Therapeutics, 32, 46-60.

Huldani. (2013). Neck Pain (Nyeri Leher). Referat. Banjarmasin: Fakultas Kedokteran UNLAM. 
Hardjono, J. \& Ervina, A. (2005). Pengaruh Penambahan Contract Relax Stretching Pada Intervensi Interferensial Current Dan Ultrasound Terhadap Pengurangan Nyeri Pada Sindroma Miofasial Otot Supraspinatus. Jurnal Fisioterapi Indonusa, 5 (1), 81-100.

Kalichman, L. \& Ben David, C. (2016). Effect of Self-myofascial Release on Myofascial Pain, Muscle Flexibility, and Strength. Journal of Bodywork \& Movement Therapies, 21, 446451.

Kisner, C. \& Colby, L.A. (2007). Therapeutic Exercise. United States of America: F. A. Davis Company.

Moore, K.L. \& Agur, A.M.R. (2002). Anatomi Klinis Dasar. (Terjemahan Hendra Laksmana). Jakarta: Hipokrates.

Moyer, C.A, Rounds, J., \& Hannum, J.W. (2004). A Meta-Analysis of Massage Therapy Research. Psychological Bulletin, 130 (1) 3-18.

Wibawa, A., Suwantini, N.W.P., \& Griadhi, I.P.A. (2015). Auto Stretching Lebih Menurunkan Intensitas Nyeri Otot Upper Trapezius Daripada Neck Cailliet Exercise pada Penjahit Payung Bali Di Desa Mengwi Kecamatan Mengwi Kabupaten Badung. Bali: Fakultas Kedokteran Universitas Udayana.

Yusuf, M. (2014). Metode Penelitian. Jakarta: Kencana. 